\title{
Removal of Landfill Leachate's Organic load by modified Electro-Fenton process
}

\author{
Azadeh erami aval ${ }^{1}$, Amir hesam hasani ${ }^{1 *}$, Ghasem Ali Omrani ${ }^{1}$, Abdolreza Karbassi ${ }^{2}$ \\ ${ }^{1}$ Department of Environmental Science, Faculty of Environment and Energy, Science and Research \\ Branch, Islamic Azad University, Tehran, Iran. \\ ${ }^{2}$ Graduate Faculty of Environment, University of Tehran, P.O.Box 14155-6135, Tehran, Iran. \\ *E-mail: hesam.hasani58@gmail.com
}

doi: $10.20964 / 2017.10 .65$

Received: 12 June 2017 / Accepted: 9 August 2017 / Published: 12 September 2017

The leachate of landfill is a potential pollutant source containing a high rate of non- biodegradable pollutants and organic resistant material. The aim of this study was to evaluate the effects of the various operating parameters such as treatment time, current voltage (potential difference), distance between the electrodes, electrode material, initial $\mathrm{pH}$ value of the solution, initial concentration of hydrogen peroxide $\left(\mathrm{H}_{2} \mathrm{O}_{2}\right)$, and the determination of optimal range by the Electro-Fenton (E-Fenton) process to remove refractory organic material from the landfill leachate. The treatment process was evaluated in a discontinuous reactor made up of a Plexiglas tank with the dimensions $20 \mathrm{~cm} \times 16 \mathrm{~cm} \times$ $10 \mathrm{~cm}$, and an effective volume of $1 \mathrm{l}$. he highest removal efficiencies of the Chemical Oxygen Demand (COD), ammonia nitrogen $\left(\mathrm{NH}_{3}-\mathrm{N}\right)$, phosphate, and turbidity were $85 \%, 30.9 \%, 78.2 \%$, and $56.2 \%$, respectively, under optimal operating conditions; these efficiencies were achieved in a duration of 30 minutes, a current voltage of $30 \mathrm{~V}$, a distance of $3 \mathrm{~cm}$ between the electrodes, an initial $\mathrm{pH}$ value of 3.5 by the iron electrode, and the addition of hydrogen peroxide in a single step with a concentration of $15 \mathrm{mg} / \mathrm{l}$. The results showed that the E-Fenton process, as a flexible technology, could be used for the treatment and the mineralization of landfill leachate with a high concentration of the pollutant.

Keywords: Current voltage, Electro-Fenton, Electrode, Turbidity

\section{FULL TEXT}

(C) 2017 The Authors. Published by ESG (www.electrochemsci.org). This article is an open access article distributed under the terms and conditions of the Creative Commons Attribution license (http://creativecommons.org/licenses/by/4.0/). 